tion, coroperation have proved to be more successful. There is no royal road to the removal of economic diffculties and the establishment of sustained-yield forests. Says Dr. Heske, writing in totalitarian Germany, "the sustained-yield private forestry of central Europe is the result of the economic and cultural situation of these countries rather than the product of legal compulsion."

In Germany a forest dictator has been appointed; whether that system will last or not, who can say? A forest dictator for Canada has been publicly advocated, even by a member of this Society. Surely Canadian foresters and Canadian forest industries are not so bankrupt of initiative, of the power of co-operation and of self-regulation that they need such an imposition. Members of the Canadian Society should also consider that if such a catastrophe occurs, this Society will probably be abolished, or at least lose its freedom of expression. Let us keep our faith in democratic and free institutions.

\title{
REFERENCES
}

British Columbia Forest Branch. Annual Reports.

British Forestry Commissioners. Annual Report. 1937.

Fairchild, F. R., Forest Taxation in the United States. U.S. Department of Agriculture.

Finland. Law Affecting Private Forests.

Guthrie, J. D., Forests of Northern Russia. Jour. of For. 22.

Heske, Franz, German Forestry, Tharandt.

Home-Grown Timber Council. Annual Report. London.

Lakari and Toijala. Main Features of Finnish Forestry. Helsinki.

Lower, A. R. M., The North American Assault on the Canadian Forest.

Mulholland, F. D., Forest Resources of British Columbia. 1917.

Saari, Eino, Forestry. And other publications. Helsinki.

Stebbing, E. P., Forests of Russia. British Forestry.

Sweden. Forest Conservation Law of Sweden. Various publications.

Information received by the writer from official sources and private individuals in Britain, Finland and Sweden, in 1937.

\section{VICTORIA SECTION'S ACTION ON FOREST POLICY}

$\mathrm{I}^{\mathrm{N}}$

N ORDER to implement the desire of the Society to assume leadership in the development of forest policy, as expressed at the 1938 annual meeting at Toronto, through the initiative of the Sections, this Section appointed a forest policy committee. This committee, under the chairmanship of $\mathrm{Mr}$. F. D. Mulholland, has held several meetings and has reported progress at two general meetings.

The last general meeting, November 6, 1939, was devoted to this subject and proved the members' interest in it by being probably the best attended meeting the Section has had.

Obviously analysis of Canadian forest policy requires the utmost latitude of enquiry and discussion, and about the only limitation recognized was the B.N.A. Act and the responsibility of provinces for natural resources. It soon became evident that in order to be of value a Section's recommendations to the Society should be based upon thorough study of past and present policy in the Section's territory and, for comparison, of forest policy elsewhere in Canada and abroad. No ill-considered recommendations should be submitted. 
Moreover it was considered that clarification of the forestry profession's ideas on this subject would be made easier if sectional organizations could construct their proposals within the same framework, so far as the differences in local conditions will allow. Therefore considerable weight was given to the form of the work done by the Quebec Association of Forest Engineers last year. On the committee's suggestion the members are dealing with policy under nine headings; Administration, Protection, Economics, Management, Social Aspects, Research, Education, Utilization, Legislation.

The procedure has been adopted of seeking, in conjunction with the other Society Section in B.C. (at Vancouver), the co-operation of all organized and informed interests, so that conclusions may have the backing of all who are concerned with forestry in this Province, particularly the Forest Services and Associations of the forest industries.

The general meeting of November 6 was devoted to the subject of Administration, which was subdivided under three heads; State forestry, private forestry, research forestry.

In addition to members of the policy committee, contributions to the discussion were made by members of the Forest Service (including the Chief Forester) and by private foresters. With regard to State forestry they centred chiefly around the desirability or otherwise of the establishment of a Provincial Forest Board or Commission.

From the discussion emerged the following ideas: that responsibility for any public policy, forest or other, must lie with the Legislature in a democracy, but that legislative bodies should be instructed and influenced, in connection with any particular policy, by the organized, informed, section of the public directly concerned with the matters with which that policy deals; in this case initiative should be taken by the forestry profession through our Society: that it is the duty and privilege of our Society to take the initiative in matters of public forest Policy, with a capital 'P,' dealing with the public interest in the use and administration of forest lands, as well as in forest policies, or rules of conduct for the protection and management of forests in all their detail; that a first essential is continuity of adequate financial provision and continuity in prosecution of sound established policies; that consideration of the possible advantages to be gained by a change in the form of State forest administration by no means implies criticism of the present public service, but rather a desire to strengthen and benefit it; that broadening the base of authority has often strengthened it by improving co-operation and eliminating opposition, and may be both efficient and democratic; finally, that many ideas on the subject have been exercising the minds of foresters, without their having an opportunity hitherto of expressing them collectively in the form of public and professional policy.

A sub-committee on Research, representing Dominion, Provincial, and University opinion, has been appointed, and other sub-committees are now being formed to deal with the other headings mentioned above.

It is hoped that, if all Sections will study and define their views on forest policy within some such framework, it will be possible in due course for the Society, by a central committee, to exercise a strong, effective, even predominant, influence upon the formation and development of Provincial and National forest policies. 